\title{
Sosialisasi Pengenalan Wakaf Terhadap Ibu-Ibu Pengajian Masjid Al-Islami Jalan Akbp H. Umar Ario Kemuning Kota Palembang
}

\section{Saprida dan Zuul Fitriani Umari}

Sekolah Tinggi Ekonomi dan Bisnis Syariah Indo Global Mandiri Palembang Universitas Islam Negeri Raden Fatah Palembang

E-mail : saprida@stebisigm.ac.id, Fitriani-uin@radenfatah.ac.id.

\begin{abstract}
This community service activity discusses the introduction of waqf from the meaning of waqf, the terms and conditions of waqf, the legal basis for waqf, various kinds of waqf, waqf objects, waqf for moving objects in the perspective of Islamic law and waqf for moving objects in the form of currency. Waqf is the use of assets to benefit from by maintaining the essence of the object and deciding the wakif's right to utilize the assets. Wakif may not do anything with the assets being donated. The purpose of this community service activity is to provide an introduction to waqf for women reciting the Al-Islami Ario Kemuning mosque in Palembang with the hope that the socialization participants can understand the benefits of giving waqf fairly and correctly. Socialization participants can also know that waqf can prosper the community and get a reward for the wakif.
\end{abstract}

Keywords: Waqf, Wakif, Mauquf'alaih.

\begin{abstract}
Abstrak
Kegiatan pengabdian masyarakat ini membahas tentang pengenalan wakaf dari pengertian wakaf, syarat dan rukun wakaf, dasar hukum wakaf, macam-macam wakaf, obyek wakaf, wakaf benda bergerak dalam perspektif hukum Islam dan wakaf benda bergerak dalam bentuk mata uang. Wakaf adalah mendayagunakan harta untuk diambil manfaatnya dengan mempertahankan dzatnya benda tersebut dan memutus hak wakif untuk mendayagunakan harta tersebut. Wakif tidak boleh melakukan apapun terhadap harta yang diwakafkan. Tujuan kegiatan pengabdian masyarakat ini memberikan pengenalan tentang wakaf terhadap ibu-ibu pengajian masjid Al-Islami Ario Kemuning palembang dengan harapan peserta sosialisasi bisa memahami akan manfaat pemberian wakaf secara adil dan benar. Peserta sosialisasai juga bisa mengetahui bahwa wakaf dapat mensejahterakan masyarakat dan mendapat pahala jariyah bagi si wakif.
\end{abstract}

Kata Kunci: Wakaf, Wakif, Mauquf 'alaih.

\section{Pendahuluan}

Wakaf telah disyariatkan dan telah dipraktikan oleh umat Islam seluruh dunia sejak zaman Nabi Muhammad SAW sampai sekarang, termasuk oleh masyarakat Islam di Negara Indonesia. Karenanya perwakafan merupakan salah satu masalah yang penting dalam rangka hubungan antara hukum Islam dengan 
hukum Nasional. Dikatakan penting karena wakaf adalah suatu amalan-amalan kegiatan keagamaan baik dibidang keagrariaan maupun bidang sarana fisik yang dapat digunakan sebagai pengembangan kehidupan keagamaan khususnya umat Islam dalam rangka mencapai kesejahteraan masyarakat baik spiritual maupun materiil menuju masyarakat yang adil dan makmur. Wakaf memainkan peran ekonomi dan sosial yang sangat penting dalam sejarah Islam, wakaf berfungsi sebagai sumber pembiayaan bagi masjid-masjid, sekolah-sekolah, pengkajian dan penelitian, rumah-rumah sakit, pelayanan sosial dan pertahanan. Sedangkan di Indonesia perwakafan sudah ada sejak lama, yaitu sebelum Indonesia merdeka, karena di Indonesia dulu pernah berdiri kerajaan-kerajaan Islam. Wakaf dalam kaitannya dengan masalah sosial ekonomi, wakaf harus dikelola secara produktif sehingga dapat memberikan kontribusi dalam meningkatkan kesejahteraan masyarakat dan membantu pemerintah dalam meningkatkan kesejahteraan dan taraf hidup masyarakat. (Akhmad Sirojudin Munir, 2015).

Wakaf merupakan salah ibadah berupa pengorbanan sebagian harta. Jika dilihat dari segi pengorbanan maka wakaf sepertinya identik dengan zakat. Namun, sebenarnya memiliki perbedaan. Seperti yang dikemukakan Setiawan, bahwa ciri utama dari wakaf adalah ketika wakaf itu telah ditunaikan maka terjadi pergeseran kepemilikan pribadi (private) menjadi kepemilikan masyarakat (public) yang diharapkan mampu memberikan manfaat secara berkelanjutan. Wakaf sebagai instrumen pendistribusian manfaat bagi masyarakat secara lebih luas atau menggeser "private benefit" menjadi "social benefit". Wakaf sebagai satu instrumen ekonomi dalam kehidupan Muslim yang mempunyai tujuan untuk mensejahterakan masyarakat. Wakaf juga dipandang sebagai bentuk instrumen unik yang lebih mendasarkan pada unsur kebijakan (birr), kebaikan (ihsan) dan persaudaraan (ukhuwah). Sehingga mengeluarkan wakaf selain beribadah juga mempunyai dimensi membantu saudara yang membutuhkan. (Syakur et al., 2018)

Salah satu tujuan didirikannya sebuah negara adalah untuk mensejahterakan rakyatnya secara adil dan makmur. Dalam konteks Indonesia, hal ini sesuai dengan bunyi sila kelima dari pancasila "keadilan sosial bagi seluruh rakyat Indonesia." Ada banyak peraturan dan kebijakan pemerintah untuk mencapai keadilan sosial bagi masyarakat Indonesia. Peraturan dibuat agar adanya kepastian hukum dalam masyarakat. Dalam banyak kasus, peraturan atau perundang-undangan bisa digunakan dalam rekayasa sosial (social engineering) untuk mencapai sebuah tujuan, jika peraturan itu tentang ekonomi, maka bisa jadi tujuannya untuk mensejahterakan masyarakat. Salah satu bidang yang bisa membantu meningkatkan kesejahteraan masyarakat adalah wakaf, terutama masyarakat muslim di Indonesia. Lembaga wakaf bersama dengan lembaga masyarakat sipil lainnya bisa jadi alternatif pemecahan masalah ketidakadilan sosial di Indonesia. Karena sejak dahulu wakaf di beberapa negara modern, dan bahkan jauh pada kesultanan pada masa lalu, telah memainkan peran yang penting dalam meningkatkan kesejahteraan masyarakat. (Suwaidi, 2011).

Wakaf merupakan salah satu tuntunan ajaran Islam yang menyangkut kehidupan bermasyarakat dalam rangka ibadah ijtimaiyah (ibadah sosial). Karena wakaf adalah ibadah, maka tujuan utamanya adalah pengabdian kepada Allah SWT dan ikhlas karena mencari ridha-Nya. Undang-Undang Nomor 41 Tahun 2004 tentang Wakaf menyebutkan bahwa wakaf adalah perbuatan hukum wakif untuk memisahkan dan/atau menyerahkan sebagian harta benda miliknya untuk 
dimanfaatkan selamanya atau untuk jangka waktu tertentu sesuai dengan kepentingannya guna keperluan ibadah dan/atau kesejahteraan umum menurut syariah. Diantara ayat yang membicarakan pendermaan harta berupa sedekah dan amal jariyah adalah QS. Al-Baqarah (2) ayat 262:

Artinya: "Orang-orang yang menafkahkan hartanya di jalan Allah, kemudian mereka tidak mengiringi apa yang dinafkahkannya itu dengan menyebut-nyebut pemberiannya dan dengan tidak menyakiti (perasaan si penerima), mereka memperoleh pahala di sisi Tuhan mereka. tidak ada kekhawatiran terhadap mereka dan tidak (pula) mereka bersedih hati".

Salah satu alasan pembentukan Undang-Undang Nomor 41 Tahun 2004 tentang Wakaf adalah praktik wakaf yang ada di masyarakat belum sepenuhnya berjalan tertib dan efisien. Salahs atu buktinya adalah bahwa diantara harta benda wakaf tidak terpelihara dengan baik, terlantar, bahkan beralih ke pihak ketiga dengan cara melawan hukum. Keadaan demikian disebabkan tidak hanya karena kelalaian atau ketidakmampuan nazir dalam mengelola dan mengembangkan benda wakaf, melainkan juga sikap masyarakat yang kurang peduli atau belum memahami status benda wakaf yang seharusnya dilindungi untuk kesejahteraan umum sesuai dengan tujuan, fungsi, dan peruntukan wakaf. (Rohman et al., 2019).

\section{Metode Pengabdian}

\section{Metode Pelaksanaan}

Rangkaian kegiatan pengabdian masyarakat adalah sebagai berikut:

1) Bentuk Kegiatan

Bentuk kegiatan yang dilakukan dalam sosialisasi tersebut adalah :

$>$ Pemaparan materi tentang wakaf.

$>$ Pemahaman dan tanya jawab tentang pelaksanaan wakaf yang benar menurut ajaran Islam.

2) Tempat Kegiatan

Adapun tempat kegiatan atau lokasi kegiatan dilaksanakan di Masjid AlIslami Jalan AKBP H. Umar Ario Kemuning Kota Palembang.

3) Proses Kegiatan

Adapun proses kegiatan dilaksanakan dalam waktu 2 hari pada hari Sabtu dan Minggu mulai tanggal 29-30 Mei 2021. Adapun kegiatan yang dilakukan selama kegiatan berlangsung adalah sebagai berikut :

a. Tanggal 29 Mei 2021:

Adapun kegiatan yang dilakukan pada pertemuan ke-1 adalah sebagai berikut :

1) Registrasi peserta

2) Penyampaian materi sesi I oleh Saprida, M.H.I. dengan judul materi pengertian zakat wakaf serta syarat dan rukun wakaf.

3) Penjelasan dasar hukum zakat wakaf dan macam-macam wakaf yang disampaikan oleh Saprida, M.H.I.

b. Tanggal 30 Mei 2021:

Dilaksanakan pada pertemuan ke-2 adalah sebagai berikut :

1) Menyampaikan materi sesi II dilakukan oleh Zuul Fitriani Umari, M.H.I dengan judul materi obyek wakaf. 
2) Penjelasan tentang wakaf benda bergerak dalam perspektif hukum Islam dan wakaf benda bergerak dalam bentuk mata uang, dibawakan oleh Saprida, M.H.I

3) Tanya jawab tentang wakaf.

4) Doa dan penutup yang dibawakan oleh Zuul Fitriani Umari, M.H.I.

\section{Waktu Kegiatan dan Materi Pokok dalam Kegiatan}

Pelaksanaan kegiatan dilakukan dalam waktu dua hari pada hari Sabtu dan Minggu Adapun jadwal pelaksanaannya adalah sebagai berikut :

Tanggal 29 Mei 2021

\begin{tabular}{|l|l|l|}
\hline \multicolumn{1}{|c|}{ Waktu } & \multicolumn{1}{|c|}{ Materi } & \multicolumn{1}{c|}{ Narasumber } \\
\hline $09.00-09.30$ & - Registrasi peserta & - Mahasiswa \\
\hline $09.30-10.00$ & - Pembukaan & $\begin{array}{l}\text { - Zuul Fitriani Umari, } \\
\text { M.H.I }\end{array}$ \\
\hline $10.00-11.00$ & $\begin{array}{l}\text { Materi: } \\
- \text { Pengertian zakat wakaf }\end{array}$ & - Saprida, M.H.I \\
\hline $11.00-12.00$ & - Syarat dan rukun wakaf & - Saprida, M.H.I \\
\hline $12.00-13.00$ & \multicolumn{2}{|c|}{ ISOMA } \\
\hline $13.00-14.00$ & $\begin{array}{l}\text { Materi: } \\
\text { - Dasar hukum wakaf }\end{array}$ & - Saprida, M.H.I \\
\hline $14.00-15.00$ & - Tanya jawab tentang wakaf & $\begin{array}{l}\text { - Zuul Fitriani Umari, } \\
\text { M.H.I }\end{array}$ \\
\hline
\end{tabular}

Tanggal 30 Mei 2021

\begin{tabular}{|c|c|c|}
\hline Waktu & Materi & Narasumber \\
\hline $09.00-10.30$ & $\begin{array}{l}\text { Materi: } \\
\text { - Macam-macam wakaf }\end{array}$ & - Saprida, M.H.I \\
\hline $10.30-12.00$ & - Obyek wakaf & $\begin{array}{l}\text { - Zuul Fitriani Umari, } \\
\text { M.H.I }\end{array}$ \\
\hline $12.00-13.00$ & \multicolumn{2}{|c|}{ ISOMA } \\
\hline $13.00-14.00$ & $\begin{array}{l}\text { Materi: } \\
\text { - Wakaf benda bergerak } \\
\text { dalam perspektif hukum } \\
\text { Islam dan wakaf benda } \\
\text { bergerak dalam bentuk mata } \\
\text { uang }\end{array}$ & - Saprida, M.H.I \\
\hline $14.00-15.00$ & - Doa dan penutup & $\begin{array}{l}\text { - Zuul Fitriani Umari, } \\
\text { M.H.I }\end{array}$ \\
\hline
\end{tabular}

Total durasi pelaksanaan pengabdian pada masyarakat untuk masing-masing pelaksana adalah :

\begin{tabular}{|c|l|c|l|c|}
\hline No & \multicolumn{1}{|c|}{ Nama } & NIDN/NPM & \multicolumn{1}{c|}{ Status } & Durasi \\
\hline 1 & Saprida, M.H.I & 2114118401 & Dosen Ekonomi & 8 Jam \\
\hline 2 & Zuul Fitriani Umari, M.H.I & 2018098604 & $\begin{array}{l}\text { Dosen } \\
\text { Manajemen } \\
\text { Zakat Wakaf }\end{array}$ & 4 Jam \\
\hline 3 & Zulkipli & 2018011041 & Mahasiswa & $1 \mathrm{Jam}$ \\
\hline
\end{tabular}




\begin{tabular}{|l|l|l|l|l|}
\hline & & & Stebis & \\
\hline
\end{tabular}

\section{Hasil dan Pembahasan}

\section{Materi Sosialisasi}

\section{A. Pengertian Wakaf}

Kata wakaf atau waqf berasal dari bahasa arab yang berasal dari akar kata wa-qa-fa berarti menahan, berhenti, diam di tempat atau berdiri. Kata waqafayaqifu-waqfan semakna dengan kata habasa-yahbisu-tahbisan maknanya terhalang untuk menggunakan. Kata waqf dalam bahasa arab mengandung makna menahan, menahan harta untuk diwakafkan, tidak dipindah milikkan. Para ulama fiqh berbeda pendapat dalam penafsiran makana wakaf, akan tetapi secara umum makna wakaf dapat dipahami sebagai menahan dzatnya benda dan memanfaatkan hasilnya atau menahan dzatnya dan menyedekahkan manfaatnya. Menurut Wahbah, perbedaan tersebut terjadi karena perbedaan mereka dalam memandang hakikat wakaf. Perbedaan pendangan tersebut dapat diuraikan sebagai berikut:

1. Abu Hanifah

Wakaf adalah menahan suatu benda dengan memberikan legalitas hukum kepada kepemilikan wakif dan menyedekahkan manfaat harta tersebut untuk kebajikan. Berdasarkan definisi itu maka pemilikan harta wakaf tidak lepas dari si wakif, bahkan ia boleh menariknya kembali dan ia boleh menjualnya. Jika si wakif wafat, harta tersebut menjadi harta warisan buat ahli warisnya. Jadi yang timbul dari wakaf hanyalah "menyumbangkan manfaat". Karena menurut Abu Hanifah bahwa wakaf bersifat sementara sehingga wakif suatu saat menguasai kembali barang yang diwakafkan. Oleh karena itu, dalam hal ini wakaf mirip transaksi pinjam-meminjam ('ariyah) karena pada dasarnya wakaf adalah menahan harta atas kepemilikannya dan mentasarufkan manfaat dari harta tersebut.

\section{Madzhab Maliki}

Madzhab Maliki berpendapat bahwa wakaf itu tidak melepaskan harta yang diwakafkan dari kepemilikan wakif, namun wakaf tersebut mencegah wakif melakukan tindakan yang dapat melepaskan kepemilikannya atas harta tersebut kepada yang lain dan wakif berkewajiban menyedekahkan manfaatnya serta tidak boleh menarik hartanya untuk digunakan oleh mustahiq (penerima wakaf), walaupun yang dimilikinya itu berbentuk upah, atau menjadikan hasilnya untuk dapat digunakan seperti mewakafkan uang. Wakaf dilakukan dengan mengucapkan lafadz wakaf untuk masa tertentu sesuai dengan keinginan pemilik. Dengan kata lain, pemilik harta menahan benda itu dari penggunaan secara kepemilikan, tetapi membolehkan pemanfaatan hasilnya untuk tujuan kebajikan, yaitu pemberian manfaat benda secara wajar sedang benda itu tetap milik si wakif. Perwakafan itu berlaku untuk suatu masa tertentu, dan karenanya tidak boleh disyaratkan sebagai wakaf kekal (selamanya).

3. Madzhab Syafi'iyah, Hanbaliyah dan sebagian Hanafiyah

Madzhab ini berpendapat bahwa wakaf adalah mendayagunakan harta untuk diambil manfaatnya dengan mempertahankan dzatnya benda tersebut dan memutus hak wakif untuk mendayagunakan harta tersebut. Wakif tidak boleh melakukan apapun terhadap harta yang diwakafkan. Berubahnya status kepemilikan dari milik seseorang, kemudian diwakafkan menjadi milik Allah. Jika wakif wafat, harta yang diwakafkan tersebut tidak dapat diwarisi oleh ahli waris. Wakif menyalurkan 
manfaat harta yang diwakafkannya kepada mauquf 'alaih (orang yang diberi wakaf) sebagai sedekah yang mengikat, dimana wakif tidak dapat melarang menyalurkan sumbangannya tersebut. Apabila wakif melarangnya, maka qadhi berhak memaksanya agar memberikannya kepada mauquf 'alaih. Karena itu madzhab ini mendefinisikan wakaf adalah tidak melakukan suatu tindakan atas suatu benda, yang berstatus sebagai milik Allah SWT, dengan menyedekahkan manfaatnya kepada suatu kebajikan (sosial). (Rizal, 2019).

\section{B. Dasar Hukum Wakaf}

Dalil yang menjadi dasar disyariatkannya ibadah wakaf bersumber dari :

1. Ayat Al-Quran, antara lain :

Artinya : Hai orang-orang yang beriman, ruku'lah kamu, sujudlah kamu, sembahlah Tuhanmu dan perbuatlah kebajikan, supaya kamu mendapat kemenangan. (Al-Hajj:7)

Artinya : Kamu sekali-kali tidak sampai kepada kebajikan (yang sempurna), sebelum kamu menafkahkan sehahagian harta yang kamu cintai. dan apa saja yang kamu nafkahkan Maka Sesungguhnya Allah mengetahuinya. (Ali Imran: 92).

2. Sunnah Rasulullah SAW.

Artinya : Abu Hurairah bahwa Rasulullah shallallahu 'alaihi wasallam bersabda: "Apabila seorang muslim meninggal, maka amalannya terputus kecuali dari tiga perkara; sedekah jariyah, ilmu yang bermanfaat, atau anak shalih yang mendoakannya". (Abu Daud: 2494). (Nissa, 2017).

\section{Syarat dan Rukun Wakaf}

Wakaf dinyatakan sah apabila telah terpenuhi rukun dan syaratnya. Menurut jumhur ulama dari mazhab Syafi'i, Maliki dan Hanbali, mereka sepakat bahwa rukun wakaf ada empat yaitu Wakif (orang yang berwakaf), Mauquf 'alaih (orang yang menerima wakaf), Mauquf Bih (harta yang diwakafkan), dan Sighat (pernyataan wakif sebagai suatu kehendak untuk mewakafkan harta bendanya). Merujuk pada sebuah badan zakat yaitu dompet dhuafa menjelaskan tentang syarat pada setiap rukun-rukun tersebut, yang pertama yaitu Wakif adalah orang yang mewakafkan dengan syarat cakap bertindak dalam membelanjakan hartanya. Kecakapan bertindak disini meliputi 4 macam kriteria, yaitu : Merdeka, Berakal sehat, Dewasa, Tidak di bawah pengampuan.

Rukun yang kedua adalah Mauquf yang diartikan sebagai benda-benda yang diwakafkan yang dipandang sah apabila memenuhi syarat-syarat benda tersebut harus mempunyai nilai, benda bergerak atau benda tetap yang dibenarkan untuk diwakafkan, benda yang diwakafkan harus tertentu (diketahui) ketika terjadi wakaf, benda tersebut telah menjadi milik si wakif. Rukun yang ketiga adalah Mauquf 'Alaih yaitu orang atau badan hukum yang berhak menerima harta wakaf dengan syarat harus dinyatakan secara tegas pada waktu mengikrarkan wakaf, kepada siapa/apa ditujukan wakaf tersebut, tujuan wakaf itu harus untuk ibadah. Rukun yang keempat adalah Shighat yaitu segala ucapan, tulisan atau isyarat dari orang yang berakad untuk menyatakan kehendak dan menjelaskan apa yang diinginkannya. Adapun syarat sahnya shighat adalah : Shighat harus 
munjazah (terjadi seketika), Shighat tidak diikuti syarat bathil. Shigaht tidak diikuti pembatasan waktu tertentu, Tidak mengandung suatu pengertian untuk mencabut kembali wakaf yang sudah dilakukan. (Purwaningsih \& Susilowati, 2020).

\section{Macam-macam Wakaf}

Bila ditinjau dari segi peruntukan ditujukan kepada siapa wakaf itu, maka wakaf dapat dibagi menjadi dua macam, yaitu:

\section{Wakaf Ahli}

Wakaf Ahli yaitu wakaf yang ditujukan kepada orang-orang tertentu, seorang atau keluarga si wakif atau bukan. Wakaf seperti ini juga disebut wakaf Dzurri. Apabila ada seseorang mewakafkan sebidang tanah kepada anaknya, lalu kepada cucunya, wakafnya sah dan yang berhak mengambil manfaatnya adalah mereka yang ditunjuk dalam pernyataan wakaf. Wakaf jenis ini (wakaf ahli/dzurri) kadang-kadang juga disebut wakaf 'alal aulad, yaitu wakaf yang diperuntukkan bagi kepentingan dan jaminan sosial dalam lingkungan keluarga (famili), lingkungan kerabat sendiri. Wakaf untuk keluarga ini secara hukum Islam dibenarkan berdasarkan Hadits Nabi yang diriwayatkan oleh Bukhari dan Muslim dari Anas bin Malik tentang adanya wakaf keluarga Abu Thalhah kepada kaum kerabatnya. Dalam satu segi, wakaf ahli (dzurri) ini baik sekali, karena si wakif akan mendapat dua kebaikan, yaitu kebaikan dari amal ibadah wakafnya, juga kebaikan dari silaturrahmi terhadap keluarga yang diberikan harta wakaf. Akan tetapi, pada sisi lain wakaf ahli ini sering menimbulkan masalah. wakaf ahli untuk saat ini dianggap kurang dapat memberikan manfaat bagi kesejahteraan umum, karena sering menimbulkan kekaburan dalam pengelolaan dan pemanfaatan wakaf oleh keluarga yang diserahi harta wakaf. Di beberapa Negara tertentu, seperti : Mesir, Turki, Maroko dan Aljazair, wakaf untuk keluarga (ahli) telah dihapuskan, karena pertimbangan dari berbagai segi, tanah-tanah wakaf dalam bentuk ini dinilai tidak produktif. (Nissa, 2017).

\section{Wakaf Khairi}

Wakaf Khairi yaitu, wakaf yang secara tegas untuk kepentingan agama (keagamaan) atau kemasyarakatan (kebajikan umum). Seperti wakaf yang diserahkan untuk keperluan pembangunan masjid, sekolah, jembatan, rumah sakit, panti asuhan anak yatim dan lain sebagainya. Jenis wakaf ini seperti yang dijelaskan dalam Hadits Nabi Muhammad SAW yang menceritakan tentang wakaf Sahabat Umar bin Khattab. Beliau memberikan hasil kebunnya kepada fakir miskin, ibnu sabil, sabilillah, para tamu, dan hamba sahaya yang berusaha menebus dirinya. Wakaf ini ditujukan kepada umum dengan tidak terbatas penggunaannya yang mencakup semua aspek untuk kepentingan dan kesejahteraan umat manusia pada umumnya. Kepentingan umum tersebut bisa untuk jaminan sosial, pendidikan, kesehatan, pertahanan, keamanan dan lain-lain. Dalam tinjauan penggunaannya, wakaf jenis ini jauh lebih banyak manfaatnya dibandingkan dengan jenis wakaf ahli, karena tidak terbatasnya pihak-pihak yang ingin mengambil manfaat. Dan jenis wakaf inilah yang sesungguhnya paling sesuai dengan tujuan perwakafan itu sendiri secara umum. Dalam jenis wakaf ini juga, si wakif (orang yang mewakafkan harta) dapat mengambil manfaat dari harta yang diwakafkan itu, seperti wakaf masjid maka si wakif boleh saja di sana, atau mewakafkan sumur, maka si wakif boleh mengambil air dari sumur tersebut 
sebagaimana pernah dilakukan oleh Nabi dan Sahabat Ustman bin Affan. Secara substansinya, wakaf inilah yang merupakan salah satu segi dari cara membelanjakan (memanfaatkan) harta di jalan Allah SWT. Dan tentunya kalau dilihat dari manfaat kegunaannya merupakan salah satu sarana pembangunan, baik di bidang keagamaan, khususnya peribadatan, perekonomian, kebudayaan, kesehatan, keamanan dan sebagainya. Dengan demikian, benda wakaf tersebut benar-benar terasa manfaatnya untuk kepentingan kemanusiaan (umum), tidak hanya untuk keluarga atau kerabat yang terbatas. (Nissa, 2017).

\section{Obyek wakaf}

Sayyid Sabiq menjelaskan bahwa benda, baik bersifat tetap (al-Uqar), maupun bergerak (al-Manqul) seperti perlengkapan rumah, mashahif, buku-buku, senjata, dan kendaraan boleh dijadikan objek wakaf. Disamping itu, setiap benda yang boleh diperdagangkan dan dimanfaatkan (dengan tetap kekal zatnya), boleh juga dijadikan objek wakaf. Sebaliknya, al- Sayyid Sabiq berpendapat bahwa benda yang rusak (berubah) karena dimanfaatkan seperti uang, lilin, makanan dan minuman, tidak syah untuk dijadikan objek wakaf. Disamping itu, al-Sayyid Sabiq menjelaskan bahwa benda-benda yang tidak boleh dijual karena zatnya seperti anjing, babi, dan binatang buas, dan tidak boleh dijual karena yang lain seperti karena digadaikan, tidak boleh dijadikan objek wakaf. Muhammad Mushthafa Syalabi menjelaskan bahwa syarat-syarat objek wakaf ada empat: Pertama, harta tersebut harus mutaqawwim (memungkinkan untuk dijaga atau dipelihara dan memungkinkan untuk dimanfaatkan dengan cara tertentu); Kedua, harta yang diwakafkan dapat diketahui secara sempurna oleh wakif dan pengelola (penerima) wakaf ketika wakaf diikrarkan; Ketiga, benda yang diwakafkan adalah milik wakif secara sempurna dan dapat dipindah tangankan ketika benda tersebut diikrarkan untuk wakaf; Keempat, benda yang diwakafkan dapat dipisahkan secara tegas tanpa terikat dengan yang lain. Pendapat ulama fqih mengenai objek wakaf memperlihatkan bahwa syarat-syarat benda wakaf (harus benda, bermanfaat, tidak sekali pakai, tidak haram zatnya, dan harus milik wakif secara sempurna) tidak didukung hadis secara khusus dan mereka menggunakan ayat-ayat Al-Quran dan Hadis yang bersifat umum. Oleh karna itu, penentuan syarat-syarat objek wakaf termasuk wilayah ijtihadi. (Naim, 2018).

\section{E. Wakaf Benda Bergerak dalam Perspektif Hukum Islam}

Fikih wakaf mengenal adanya dua bentuk wakaf apabila dilihat dari konteks kemungkinan pemindahannya; yaitu: wakaf benda tidak bergerak (waqf al-'iqâr) dan wakaf benda bergerak (waqf al-manqûl). Benda tidak bergerak (al-'iqâr) adalah benda yang tidak bisa dipindahkan dari tempatnya semula, seperti rumah dan tanah atau sesuatu yang tetap. Sementara, yang disebut dengan benda bergerak (al-manqûl) adalah benda yang bisa dipindahkan dari tempatnya semula, atau sesuatu yang bisa dipindahkan dari satu tempat ke tempat lainnya seperti mata uang, binatang, timbangan dan sebagainya. Selanjutnya, para ulama berbeda pendapat dalam hal kategorisasi kedua bentuk harta tersebut; apakah benda yang berubah bentuknya ketika dipindahkan itu disebut benda tidak bergerak atau benda bergerak seperti bangunan dan pepohonan. Dalam hal ini, ada dua pendapat yang berbeda: 
1. Pendapat ulama Hanafiyah yang menyatakan bahwa benda tersebut termasuk ke dalam benda bergerak (al-manqûl) kecuali apabila bangunan dan pepohonan tersebut tetap di atas tanah.

2. Pendapat Jumhur Ulama selain Hanafiyah menyatakan bahwa benda tersebut masuk dalam kategori benda tidak bergerak (al-'iqâr).

Dari beberapa perbedaan pendapat para ulama atas definisi dan kategorisasi benda tidak bergerak (al-'iqâr) dan benda bergerak (al-manqûl) ini, mempengaruhi pula pada keabsahan tindakan wakaf atas dua kategorisasi benda wakaf tersebut. Keabsahan mewakafkan harta tidak bergerak menjadi dalil atas keabsahan mewakafkan harta bergerak selama memegang prinsip menahan pokok dan menyalurkan manfaatnya (tahbîs al-ashl wa tasbîl al-manfaah). Imam alMawardi berkata bahwa wakaf benda tidak bergerak adalah sah dengan tanpa perdebatan sebagaimana mereka juga sepakat (ijma') atas keabsahan mewakafkan benda bergerak yang mengikuti keabsahan wakaf benda tidak bergerak. Imam alZayla'iy berkata bahwa wakaf benda bergerak mengikuti wakaf benda tidak bergerak adalah diperbolehkan berdasarkan kesepakatan para ulama (ijma'). Adapun beberapa pernyataan para ulama atas keabsahan wakaf benda tidak bergerak dan benda bergerak adalah sebagai berikut:

a) Imam Abu Hanifah dan berdasarkan periwayatan Imam Ahmad menyatakan bahwa wakaf benda bergerak adalah tidak sah.

b) Mazhab Maliki, Syafi'i dan yang masyhur di kalangan ulama mazhab Hanbali menyatakan bahwa tidak ada perbedaan antara benda tidak bergerak dan benda bergerak di dalam wakaf. Semuanya menyatakan sah dalam wakaf.

Pendapat Abu Yusuf dari Mazhab Hanafi menyatakan bahwa yang termasuk kategori benda bergerak yang sah dalam wakaf hanya mencakup persenjataan dan hewan (kuda dan keledai). Sementara itu, pendapat Muhammad Ibn al-Hasan alSyaybani dari Mazhab Hanafi menyatakan sah wakaf benda bergerak berdasarkan adat kebiasaan wakaf di suatu tempat. (Rafiqi, 2018)

\section{F. Wakaf Benda Bergerak dalam Bentuk Mata Uang}

Perbincangan tentang wakaf tunai mulai mengemuka dalam beberapa tahun belakangan ini. Hal ini terjadi seiring berkembangnya sistem perekonomian dan pembangunan yang memunculkan inovasi-inovasi baru. Wakaf tunai sebagai instrumen finansial (financial instrument), keuangan sosial dan perbankan sosial (social finance and voluntary sector banking) dipelopori oleh Prof. M.A. Mannan (2002), pakar ekonomi asal Bangladesh. Wakaf tunai yang digagas oleh Mannan merupakan produk baru dalam sejarah perekonomian Islam. Instrumen finansial yang dikenal dalam perekonomian Islam selama ini berkisar pada murabahah untuk membiayai sektor perdagangan dan mudarabah atau musyarakah untuk membiayai investasi di bidang industri dan pertanian. Bank juga tidak mau menerima tanah atau aset lain yang merupakan harta wakaf untuk dijadikan jaminan. Karena harta wakaf bukan hak milik, melainkan hak pakai terhadap manfaat harta wakaf itu. (Rafiqi, 2018).

\section{E. Hikmah Wakaf}


Ibadah wakaf yang tergolong pada perbuatan sunah ini banyak sekali hikmahnya yang terkandung dalam wakaf ini, antara lain:

1. Harta benda yang diwakafkan dapat tetap terpelihara dan terjamin kelangsungannya. Tidak perlu khawatir barangnya hilang atau pindah tangan, karena secara prinsip barang wakaf tidak boleh ditasarufkan, apakah itu dalam bentuk menjual, dihibahkan atau diwariskan.

2. Pahala dan keuntungan bagi si wakif akan tetap mengalir walaupun suatu ketika ia telah meninggal dunia, selagi benda wakaf itu masih ada dan dapat dimanfaatkan. Oleh sebab itulah, diharuskan benda wakaf itu tahan lama. Dalam keadaan seperti ini wakaf sebagai inventaris untuk meraih keuntungan pahala dari Allah. Selain itu mendapat balas an di dunia. Baik kepuasan batin atau semakin tercipta nya ikatan ukhuwah Is-lamiyah bagi mereka. Terhadap perbuatan-perbuatan yang baik, akan senantiasa mengalir pahalanya setelah meninggal dunia. Disebutkan Rasulullah dalam sebuah Hadis yang diriwayatkan Ibnu Majah, "Sesungguhnya sebagian amalan dan kebaikan orang yang beriman yang dapat mengikutinya sesudah ia meninggal ialah ilmu yang disebarluaskan, anak soleh yang ditinggal kan, Al-Qur'an yang diwariskan, masjid yang didirikan, rumah yang dibangun untuk musafr, sungai yang dialirkan, atau sedekah yang ia keluarkan dari harta bendanya pada waktu ia masih sehat/hidup. Sedekah ini juga dapat menyusulnya sesudah orang tersebut meninggal dunia".

3. Wakaf merupakan salah satu sumber dana yang sangat pen-ting manfaatnya bagi kehidupan agama dan umat. Antara lain untuk pembinaan mental spiritual dan pembangunan segi fisik. Mengingat besarnya hikmah dan manfaatnya terhadap kehidupan umat, maka Nabi Muhammad saw. sendiri dan para sahabat dahulu dengan ikhlas mewakafkan masjid, tanah, sumur, kebun dan kuda milik mereka serta harta benda lainnya untuk kemajuan agama dan umat Islam umumnya. Langkah Nabi dan para sahabat itu kemudian kita ikuti hingga sampai sekarang ini, walaupun belum begitu terkelola secara maksimal. (Dr. Qodariah Barkah et al., 2020).

\section{F. Hasil Sosialisasi}

Dari sosialisasi yang narasumber dan panitia kepada ibu-ibu pengajian di masjid Al-Islami Ario Kemuning diharapkan para ibu-ibu pengajian dapat memahami materi tentang wakaf secara terperinci. Dengan kegiatan tersebut semoga narasumber dan peserta mendapat wawasan tentang wakaf diantaranya sebagai berikut :

1. Peserta ibu-ibu pengajian masjid Al-Islami bisa memahami wakaf secara terperinci.

2. Para ibu-ibu pengajian masjid Al-Islami bisa memahami tentang syarat dan rukun wakaf.

3. Para ibu-ibu pengajian masjid Al-Islami memahami macam-macam wakaf.

4. Para peserta sosialisasi bisa memahami obyek wakaf.

5. Para peserta sosialisasi diskusi dan tanya jawab tentang wakaf.

\section{Simpulan}


Berdasarkan beberapa kegiatan yang telah narasumber beserta panitia lakukan pada pengabdian masyarakat tentang wakaf di masjid Al-Islami Ario Kemuning Palembang maka dapat diambil beberapa kesimpulan :

1. Kegiatan ini sangat bermanfaat bagi peserta sosialisasi tentang wakaf, santriwati membutuhkan tambahan pengetahuan tentang penerapan wakaf secara benar menurut ajaran Islam.

2. Kegiatan pengabdian masyarakat ini juga membantu para peserta sosialisasi tentang pengertian wakaf, syarat dan rukun wakaf, dalil tentang wakaf, macam-macam wakaf dan obyek wakaf.

3. Meningkatkan pengetahuan peserta sosialisasi bahwa dengan adanya pembagian wakaf yang benar memperbaiki perekonomian seluruh masyarakat.

4. Para peserta sosialisasi memahami wakaf benda bergerak dalam persepektif hukum Islam.

5. Ibu-ibu pengajian masjid Al-Islami yang mengikuti sosialisasi wakaf melakukan diskusi dan tanya tanya secara menyeluruh tentang wakaf. 


\section{Daftar Pustaka}

Akhmad Sirojudin Munir. (2015). Optimalisasi Pemberdayaan Wakaf Secara Produktif. Ummul Quro, 6(Jurnal Ummul Qura Vol VI, No 2, September 2015), 94-109. http://ejournal.kopertais4.or.id/index.php/qura/issue/view/531

Dr. Qodariah Barkah, M. H. ., Dr. Peny Cahaya Azwari, S.E., M.M, MBA., Ak., C., Saprida, M. H. ., \& Zuul Fitriani Umari, M. H. . (2020). fikih zakat, sedekah, dan wakaf. Prenadamedia Group.

Naim, A. H. (2018). Pengembangan Objek Wakaf Dalam Fiqih Islam Dan Hukum Positif Di Indonesia. ZISWAF: Jurnal Zakat Dan Wakaf, 4(2), 245. https://doi.org/10.21043/ziswaf.v4i2.3044

Nissa, C. (2017). Sejarah, Dasar Hukum Dan Macam-Macam Wakaf. Jurnal Keislaman, Kemasyarakatan \& Kebudayaan, 18(2), 205-219.

Purwaningsih, S., \& Susilowati, D. (2020). Peran Wakaf Dalam Meningkatkan Pemberdayaan Ekonomi Umat. Jurnal Ekonomi, Bisnis, Dan Akuntansi, 22(2), 191-203. https://doi.org/10.32424/jeba.v22i2.1595

Rafiqi, Y. (2018). Wakaf Benda Bergerak Dalam Perspektif Hukum Islam Dan Perundang-Undangan Di Indonesia. Al-Mashlahah: Jurnal Hukum Islam Dan Pranata Sosial, 6(02), 191. https://doi.org/10.30868/am.v6i2.307

Rizal, F. (2019). Wakaf Non Muslim Dan Wakaf Uang Menurut Pandangan Wahbah Zuhaili. Al-Intaj : Jurnal Ekonomi Dan Perbankan Syariah, 5(2), 176. https://doi.org/10.29300/aij.v5i2.2059

Rohman, A. N., Sugeng, S., Rahayu, P., \& Saifulloh, P. P. A. (2019). Penyuluhan Hukum Tentang Urgensi Sertifikasi Tanah Wakaf Di Kelurahan Harapan Baru Kota Bekasi. Jurnal ABDIMAS UBJ, 2(1), 50-60. http://jurnal.ubharajaya.ac.id/index.php/jabdimas/article/view/50-60

Suwaidi, A. (2011). Wakaf Dan Penerapannya Di Negara Muslim. Jurnal Ekonomi Dan Hukum Islam, 1(2), 94-116.

Syakur, A., Yuswadi, H., Sunarko, B. S., \& Wahyudi, E. (2018). Tata Kelola Wakaf dalam Meningkatkan Kesejahteraan Masyarakat di Kabupaten Jember. AL-IHKAM: Jurnal Hukum \& Pranata Sosial, 13(1), 73. https://doi.org/10.19105/al-ihkam.v13i1.1187 